\section{Occupational asthma due to latex in health care workers}

\author{
Alice Ho, Henry Chan, Kam S Tse, \\ Moira Chan-Yeung
}

\begin{abstract}
Immediate hypersensitivity reactions ranging from mild urticaria to life threatening anaphylaxis after exposure to natural rubber latex have been reported frequently in health care workers while occupational asthma due to latex exposure is less well studied. The results of specific challenge tests and immunological tests in four health care workers with work related respiratory and skin disorders induced by the use of latex gloves are described. Occupational asthma was confirmed in three subjects by specific challenge tests. All had a positive skin test reaction to the latex extract; specific IgE antibodies were detected in only one subject. The fourth subject had a negative specific inhalation and skin test reaction to the latex extract. Peak expiratory flow monitoring at work and away from work showed a pattern consistent with work related asthma. These findings confirm that latex is a cause of occupational asthma in health care workers.

(Thorax 1996;51:1280-1282)
\end{abstract}

Keywords: asthma, occupational disease, latex, specific bronchial challenge.

There have been numerous reports of immediate hypersensitivity reactions to natural rubber from occupational exposure in health care workers. ${ }^{12}$ The reactions to latex were found to be mediated by immunoglobulin $\mathrm{E}$ (IgE). ${ }^{34}$ While contact urticaria is the most frequent clinical manifestation, rhinitis, conjunctivitis, angioedema, asthma, and life threatening anaphylaxis have also been reported as parts of a generalised reaction following contact with latex. ${ }^{4-6}$ The diagnosis of allergic reactions to latex is usually based on skin prick testing and/or demonstration of specific IgE in the serum. Bronchoprovocation testing has been used in the diagnosis of latex induced asthma. ${ }^{7}$ Standardised materials for skin testing and for detecting specific IgE antibodies are not yet commercially available. ${ }^{8}$ We present a report of three subjects with latex induced asthma proven by specific challenge tests and a fourth with occupational asthma possibly related to latex exposure. The results of skin tests and measurement of specific IgE antibodies are also presented.

\section{Methods}

SUBJECTS

Four consecutive subjects with symptoms of asthma related to exposure to latex gloves re- ferred to the University of British Columbia respiratory clinic were studied.

Subject 1, an operating room nurse, had experienced itchy eyes and nose and skin rash for five years whenever she used latex gloves. For the past two and a half years she also complained of difficulties in breathing, particularly at night after work. These symptoms disappeared after she stopped using latex gloves. Subject 2, another operating room nurse, had a non-productive cough, chest tightness, wheezing, and difficulty in breathing for 18 months when first seen in the clinic. She also had skin rashes and periorbital oedema after exposure to latex. Her symptoms improved whenever she was on holiday. Subject 3, a dental assistant, had a history of eczema during childhood. She noticed itchy skin rashes over the knuckles of her hands whenever she wore latex gloves. Cough with sputum production and chest tightness were present for four months before she was referred to the clinic. Her symptoms improved after she changed her job location. Subject 4 , a nurse from a burn unit, had suffered contact dermatitis and nasal symptoms after exposure to latex gloves for five years. She had had difficulty in breathing for two years, especially at night, and required bronchodilators for relief. When she changed her job and avoided exposure to latex her symptoms improved and she was able to discontinue all medications.

\section{SKIN TESTING}

Skin prick tests were done using a battery of common allergens including house dust mite extracts containing $D$ pteronyssinus, $D$ farinae, histamine $(2.5 \mathrm{mg} / \mathrm{ml})$ as a positive control, and saline as a negative control. In addition, serial dilutions of latex extract (Omega Laboratory, Montreal) containing 31.3, 62.5, 125, $250,500,1000,2000$ protein nitrogen units (pnu) $/ \mathrm{ml}$ were prepared for skin prick tests. A positive reaction was defined as the presence of a weal $3 \mathrm{~mm}$ or greater than a negative control 15 minutes after testing.

MEASUREMENT OF SPECIFIC IGE ANTIBODIES Specific IgE antibodies against latex were measured using paper radioimmunosorbent test (PRIST) with commercially available discs (Latex, K 82, Pharmacia Diagnostics AB, Uppsala, Sweden). The test was performed according to the manufacturer's instructions and the results were expressed as Phadebas RAST units $(\mathrm{pru}) / \mathrm{ml}$. Values of more than $0.35 \mathrm{pru} /$ $\mathrm{ml}$ were considered positive. Total IgE in serum was also measured by radioimmunoassay using kits from Pharmacia (Uppsala, Sweden).

\section{METHACHOLINE CHALLENGE TEST}

A methacholine challenge test was carried out using the tidal breathing method previously described. ${ }^{9}$ Briefly, increasing concentrations of methacholine were given by inhalation at intervals of five minutes, each for a period of two minutes, after initial inhalation of normal 
Table 1 Results of specific challenge testing and immunological data

\begin{tabular}{|c|c|c|c|c|c|}
\hline \multirow{2}{*}{$\begin{array}{l}\text { Case } \\
\text { no. }\end{array}$} & \multicolumn{2}{|c|}{ Maximum fall in FEV 1 pattern (\%) } & \multirow{2}{*}{$\begin{array}{l}\text { Skin test reaction } \\
\text { to latex }\end{array}$} & \multirow{2}{*}{$\begin{array}{l}\text { PRIST } \\
\text { (pru/ml) }\end{array}$} & \multirow{2}{*}{$\begin{array}{l}\text { Total IgE } \\
(k U / l)\end{array}$} \\
\hline & $\begin{array}{l}\text { Within } 30 \\
\text { minutes }\end{array}$ & $\begin{array}{l}\text { Within 2-6 } \\
\text { hours }\end{array}$ & & & \\
\hline $\begin{array}{l}1 \\
2 \\
3 \\
4\end{array}$ & $\begin{array}{r}6 \\
30 \\
23 \\
20\end{array}$ & $\begin{array}{r}9 \\
13 \\
9 \\
23\end{array}$ & $\begin{array}{l}\text { Negative } \\
\text { Positive } \\
\text { Positive } \\
\text { Positive }\end{array}$ & $\begin{array}{l}<0.35 \\
<0.35 \\
22.0 \\
<0.35\end{array}$ & $\begin{array}{l}6.1 \\
33.5 \\
143 \\
100\end{array}$ \\
\hline
\end{tabular}

$\mathrm{FEV}_{1}=$ forced expiratory volume in one second.

saline. Forced expiratory volume in one second $\left(\mathrm{FEV}_{1}\right)$ and forced vital capacity (FVC) were measured at baseline and at 30 seconds and three minutes after each inhalation. Inhalation was discontinued when there was a fall in $\mathrm{FEV}_{1}$ of $20 \%$ or more from the post-saline level or when a concentration of $32 \mathrm{mg} / \mathrm{ml}$ had been given at the end of the inhalation challenge test. The $\mathrm{PC}_{20}$ methacholine (concentration of methacholine eliciting a $20 \%$ fall from the lowest post-saline value) was obtained from interpolation of the non-cumulative doseresponse curve on a semilogarithmic scale. Spirometric tests were performed every $15 \mathrm{~min}$ utes during the first hour, hourly for six hours, and again at 24 hours. Peak expiratory flow rate (PEF) was measured before and at the same interval after inhalation challenge as $\mathrm{FEV}_{1}$ using a mini-Wright peak flow meter. The subjects continued to measure their PEF hourly after they left the laboratory until bedtime. The variation in PEF was less than $10 \%$ for each subject after recovery from the methacholine challenge test.

SPECIFIC CHALLENGE TESTS

A specific challenge test was carried out as described previously. ${ }^{9}$ Saline was given fol-
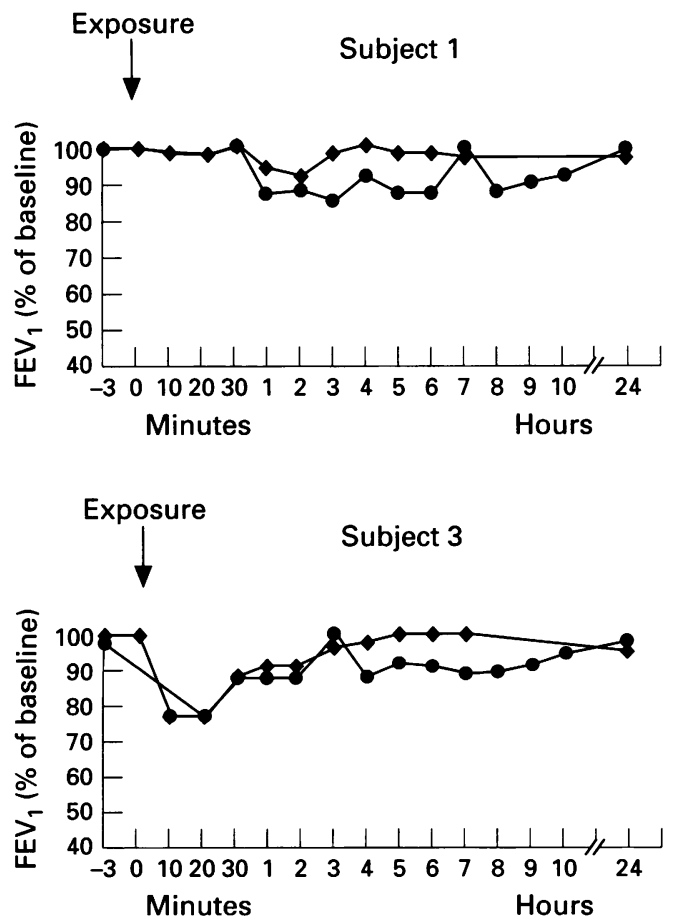

lowed by increasing concentrations of latex extract. The initial concentration of latex extract used in each subject was the one that produced a weal diameter of less than $3 \mathrm{~mm}$. Both saline and each concentration of latex were given by tidal breathing for a period of two minutes. When the $\mathrm{FEV}_{1}$ fell by less than $20 \%$ the next higher concentration was given. Inhalation testing was discontinued when the $\mathrm{FEV}_{1}$ fell by $20 \%$ or more from the lowest postsaline value or the maximum concentration of $2000 \mathrm{pnu} / \mathrm{ml}$ was given. After testing, $\mathrm{FEV}_{1}$ was monitored at $5,10,15,30$, and 60 minutes and then hourly for six hours and again at 24 hours. PEF was also monitored before and at intervals after the challenge as well as hourly after the patient left the laboratory at the end of six hours until bedtime. A fall in $\mathrm{FEV}_{1}$ of more than $20 \%$ from the baseline within 30 minutes of the challenge was considered a positive immediate reaction while a similar fall in $\mathrm{FEV}_{1}$ 3-10 hours after the challenge was considered a positive late asthmatic reaction.

\section{Results}

Three of the four subjects gave a history of allergic rhinitis but none had pre-existing asthma. Three were non-smokers and one was an ex-smoker at the time of the investigation. Their ages ranged from 25 to 42 years. Only one subject had positive immediate skin reactions to common allergens. All subjects had direct and regular exposure to latex gloves for periods ranging from two to 10 years before the onset of asthma symptoms. They also had contact urticaria whenever they wore latex gloves and two had associated rhinoconjunctivitis.

The diagnosis of occupational asthma was confirmed by a positive specific challenge test
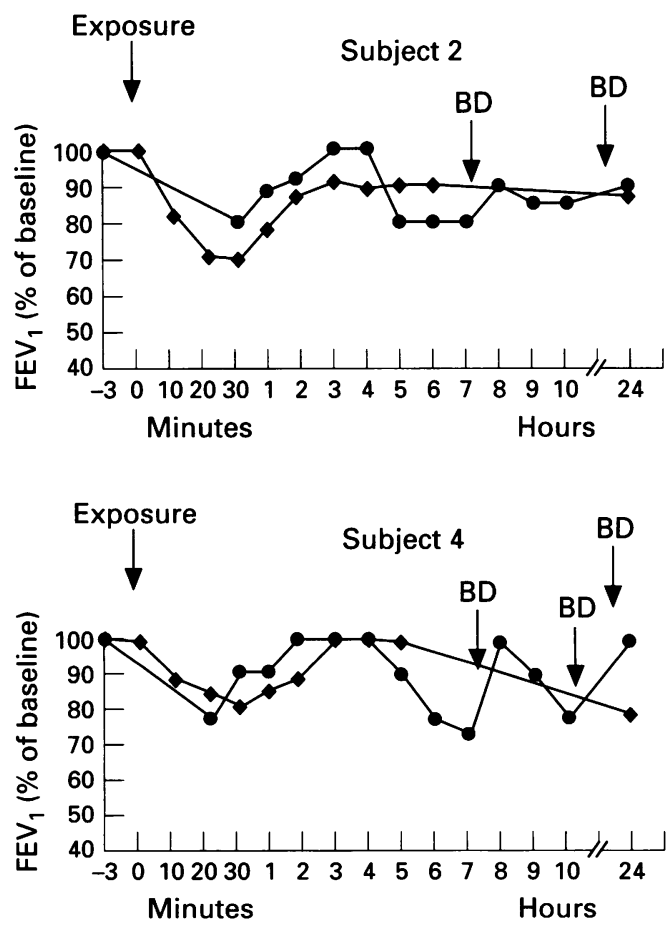

Figure 1 Results of specific inhalation challenge testing with a latex extract in the four subjects showing changes in forced expiratory volume in one second (FEV) after inhalation of latex extract. $B D=$ inhaled bronchodilator. 


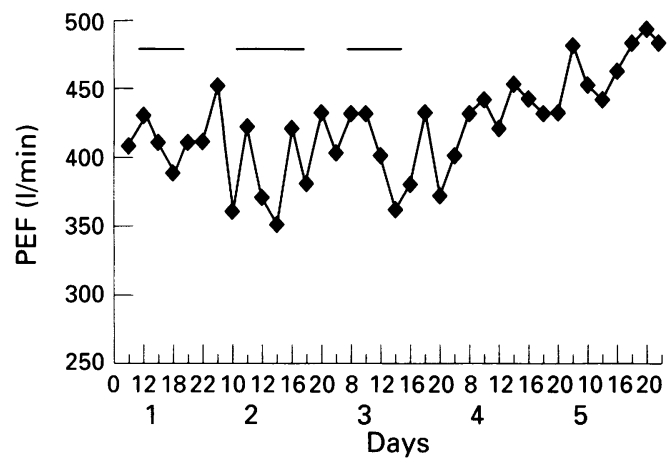

Figure 2 Peak expiratory flow (PEF) record of subject 1 showing improvement in PEF when she was away from work. The horizontal lines indicate the days on which the subject was at work.

with the latex extract in three patients (subjects 2, 3, and 4) (table 1, fig 1) who developed immediate asthmatic reactions after inhalation challenge. Subject 4 also had a late asthmatic response which started six hours after challenge and lasted for more than 24 hours (fig 1). A positive immediate skin reaction to the latex extract was found in all three patients. Specific IgE antibodies against latex were found in only one patient by PRIST. Subject 1 had a negative specific challenge test and negative skin prick test and PRIST to the latex extract. PEF monitoring was carried out during days at and away from work and a progressive increase in PEF was found when she was away from work (fig 2).

\section{Discussion}

Latex allergy among health care workers is becoming increasingly recognised. Occupational asthma due to latex exposure has been reported in several studies. ${ }^{6810}$ Diagnostic procedures used to confirm a relationship with work have included specific challenge tests, monitoring of peak expiratory flow, and immunological testing. ${ }^{7811}$ Our four patients had a history of improvement in symptoms when away from work and recurrence of symptoms on returning to work. However, it has been shown that history alone is neither sensitive nor specific for the diagnosis of occupational asthma. ${ }^{12}$ Objective tests were done to confirm the work-relatedness of their symptoms.

In previous studies the diagnosis of latex induced asthma was confirmed by exposing the subjects to latex glove powder rather than by using an extract. ${ }^{71314}$ In this study we used a commercially available latex extract for skin tests and specific challenge tests. Three subjects had both positive immediate asthmatic and skin reactions to this extract (one also had a late asthmatic reaction), confirming that their asthma was due to latex exposure. One subject did not have bronchial or skin test reactions to this extract but her PEF record was compatible with occupational asthma. It is possible that this patient may have asthma due to other contaminants in the workplace. On the other hand, the avoidance of exposure to latex gloves led to amelioration of her symptoms which suggests that latex exposure could be the cause of her asthma and that the extract used in this study did not contain all the antigens.

Skin testing with the latex allergen has been shown to have a sensitivity of approximately $90 \%$ and a specificity of almost $100 \%$ for latex allergy. ${ }^{1516}$ It has been found to be a useful screening tool in subjects with suspected latex allergy. ${ }^{1516}$ Specific IgE antibodies were found in only one subject in this study $(25 \%)$. Measurement of specific IgE antibodies by RAST for latex allergy has a sensitivity varying from $14 \%$ to $87 \% .^{10}{ }^{17-20}$ These studies were largely carried out with unstandardised materials.

In summary, establishing the diagnosis of latex induced asthma in health care workers is essential to avoid permanent respiratory disability. Skin prick tests and specific challenge tests are useful methods of diagnosis while serological testing was not found to be useful in this study using the commercially available extract. The availability of a standardised latex extract for immunological testing will greatly improve the diagnostic accuracy of allergy to latex.

1 Levy DA, Chapin D, Pecquet C, Leynadier F, Vervloet D. Allergy to latex. Allergy 1992;47:579-87.

2 Slater JE. Allergy reactions to natural rubbers. Ann Allergy 1992;68:203-8.

3 Wrangsio K, Wahlberg JE, Axelsson IGK. IgE-mediated allergy to natural rubber in 30 patients with contact dermatitis. Contact Dermatitis 1988;19:264-71.

4 Sussman G, Talo S, Dolovich J. The spectrum of IgEmediated responses to latex. $7 A M A$ 1991;265:2844-7.

Slater JE. Rubber anaphylaxis. $N$ Engl $f$ Med 1989;27: $1127-30$.

6 Marco C, Lazaro M, Fraj J, Quirce S, de la Hoz B, Fernandez-Rivas $M$, et al. Occupational asthma due to latex surgical gloves. Ann Allergy 1991;67:319-23.

7 Pisati G, Baruffini A, Bernabeo F, Stanizzi R. Bronchial provocation testing in the diagnosis of occupational asthma due to latex surgical gloves. Eur Respir f 1994;7:332-6.

8 Vandenplas $O$. Occupational asthma caused by natural rubber latex. Eur Respir $\mathcal{F}$ 1995;8:1957-65.

9 Lam S, Wong R, Chan-Yeung M. Non-specific bronchial reactivity in occupational asthma. $\mathcal{f}$ Allergy Clin Immunol 1979;63:28-34.

10 Lagier F, Vervloet D, Lhermet I, Poyen, Ckapin D. Prevalence of latex allergy in operating nurse. $\mathcal{F}$ Allergy Clin Immunol 1992;90:319-22.

11 Cartier A. Definition and diagnosis of occupational asthma. Eur Respir f 1994;7:153-60.

12 Malo JL, Ghezzo H, L'Archeveque J, Lagier F, Perrin B, Cartier $\mathrm{A}$. Is the clinical history a satisfactory means of diagnosing occupational asthma? Am Rev Respir Dis 1991 143:528-32.

13 Brugnami G, Marabini A, Siracusa A, Abbritti G. Workrelated late asthmatic response induced by latex allergy. $\mathcal{f}$ Allergy Clin Immunol 1995;96:457-64.

14 Vandenplas O, Delwiche JP, Evrard G, Aimont P, Brempt XVD, Jamart J, et al. Prevalence of occupational asthma due to latex among hospital personnel. Am $\mathcal{F}$ Respir Crit Care Med 1995:151:54-60.

15 Turjanmaa K, Alenius H, Makinen-Kilijunen S, Palosuo T, Reunala $\mathrm{T}$. Commercial skin prick test preparations in the diagnosis of rubber latex allergy. F Allergy Clin Immunol 1994;93:299.

16 Hadjiliadis D, Khan $\mathrm{K}$, Tarlo SM. Skin test responses to latex in an allergy and asthma clinic. $\mathcal{F}$ Allergy Clin Immunol latex in an allergy

17 Kelly KJ, Kurup V, Zacharisen M, Resnick A, Fink JN. Skin and serological testing in the diagnosis of latex allergy.

18 Turjanmaa K, Reunala T. Comparison of diagnostic methods in latex surgical glove contact urticaria. Contact Dermatitis 1988;19:241-7.

19 Moneret-Vautrin D, Beaudouin E, Widmer S, Mouton C, Kanny G, Prestat F, et al. Prospective study of risk factors in natural rubber latex hypersensitivity. F Allergy Clin Immunol 1993;92:668-77.

20 Slater JE, Mostello LA, Shaer C. Rubber-specific IgE in children with spina bifida. F Urol 1991;146:578-9. 